Economics Development Analysis Journal

\title{
Relationship of The Economy and Investment Sector on The Implementation of Labor Central Sector of Central Java
}

Rifa Atun Mahmudah ${ }^{凶}$

Economics Development Department, Economics Faculty, Universitas Negeri Semarang

\section{Article Info}

Article History :

Received July 2016

Accepted September 2016

Published November

2016

Keywords:

Input-Output;

Investment; Labor

Absorption; Economics

Sector

\begin{abstract}
This study aimed to analyze the linkages between sectors, multiplier and the investment sector's role in increasing the amount of output and the amount of labor that can be absorbed in the economy in the Province of Central Java. This study used a quantitative approach with secondary data. The analytical tool used was the analysis of input-output tables Province of Central Java in 2013 primarily relies on domestic transactions table on the basis of producer prices. The results showed the role of economy based on the analysis forward linkages and backward linkages can be divided into leading sectors, growing sector, potential sectors and underdeveloped sector. Sectors with the highest output multiplier is the manufacturing sector. Sector with the highest labor multiplier is the agricultural sector. The results also showed that the leading sectors also have a growing sectors impact on the highest output and labor absorption of final demand investment, that is trade, hotels and restaurants; Manufacturing Industry; and agriculture. Increased investment will increase the value of output and an increase in output will increase employment. At last, investments have a positive relationship with employment.
\end{abstract}




\section{INTRODUCTION}

Regional economic development is a process whereby local governments and communities manage the existing resources, form a partnership pattern between local governments and private sectors in order to create new jobs and also stimulate the development of economic growth in the region. Investment is considered as one of the main factors in economic development. As it will lead to full utilization of existing resources and in its turn will result increased output and employment. Furthermore, private investment has a positive and significant influence on employment (Jamaliah, 2016). In line with this, development planners often face the problems of inequality. One of the causes is the uneven spread of investments in both regional and sectorial scope. In the regional sphere, investment in Indonesia is still widely spread on Java Island. According to the Investment Coordinating Board (BKPM), in the period 20102014 there has been an increase in the spread of investment in almost all regions outside Java. Investment contributions outside Java increased from an average of $23.0 \%$, in the 2005-2009 period, $40.6 \%$ in the $2010-2014$ period. It means that the contribution of investment in Java Island with the percentage of $59.4 \%$ still dominates in Indonesia. The interest of investors to invest in Java is constantly high.

Table 1. Domestic Investment (PMDN) and Foreign Investment (PMA) Realization by Province in Java Islands Year 2013

\begin{tabular}{llll}
\hline Province & $\begin{array}{l}\text { PMDN Investment } \\
\text { (Billion Rupiah) }\end{array}$ & $\begin{array}{l}\text { Investment PMA } \\
\text { (Billion Rupiah) }\end{array}$ & $\begin{array}{l}\text { Number of Investment } \\
\text { Value } \\
\text { (Billion Rupiah) }\end{array}$ \\
\hline DKI Jakarta & $5,754.50$ & $35,349.10$ & $41,103.60$ \\
West Java & $9,006.10$ & $97,201.40$ & $106,207.50$ \\
Central Java & $12,593.60$ & $6,334.20$ & $18,927.80$ \\
DI Yogyakarta & 283.8 & 403.8 & 687.60 \\
East Java & $34,848.90$ & $46,334.00$ & $81,182.90$ \\
Banten & $4,008.70$ & $50,752.80$ & $54,761.50$ \\
\hline
\end{tabular}

Source: Investment Coordinating Board, Data processed

Based on Table 1 above, it can be seen that the highest investment value is in West Java Province with investment value of Rp106, 207.50 billion, while investment value in Central Java Province is included as the lowest investment value compared to other provinces in Java Island. In fact, Central Java Province has larger area and greater population rather than Yogyakarta, so it has an opportunity to strongly improve services and ease investment. To see the performance of development on investment affairs in Central Java can be illustrated through indicators such as the number of Foreign Investment Investors (PMA) and Domestic Investment (PMDN), project approval, its value and realization of investment, and the ratio of labor absorption.

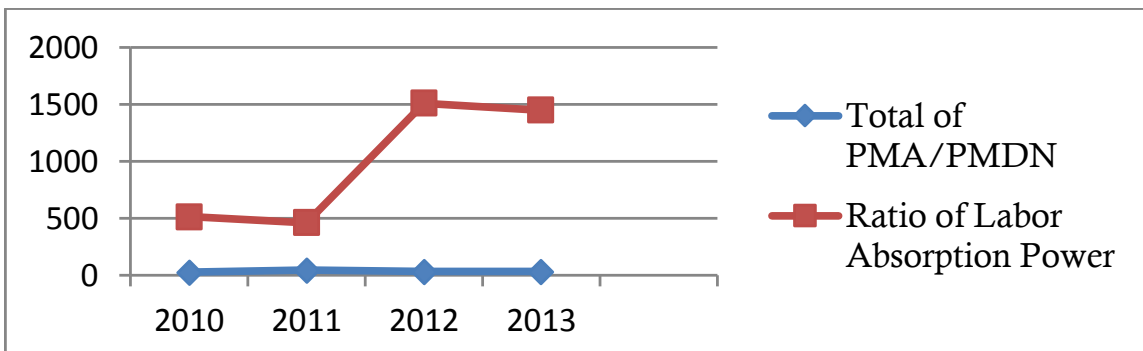

Figure 1. Growth of PMA / PMDN and Ratio of Labor Absorption in Central Java Province in 2010-2013.

Source: BPMD Central Java Province, 2015, Data processed 
Based on development performance indicators on investment affairs particularly the number of PMA / PMDN and the labor absorption ratio in Central Java Province 20102013, it can be seen that the increase of investment PMA/ PMDN amount does not always increase the labor absorption ratio, vice versa. This indicates a problem, because when investment increases then employment opportunities will also increase, so absorbed labor will.

Regarding the above condition, regional economic and employment issues need to be concerned in development planning. The provision of extensive employment is urgently needed to balance the rate of growth of productive age population which enters the labor market. In addition, unemployment issues will also lead to other social problems. In line with above explanation, as one of the efforts in development planning, it is necessary to research about the role of economic sector and influence of investment in the economic structure, especially sectors in investment as an effort to absorb labor. Eventually it will have an important role in economic growth achievement.

\section{RESEARCH METHOD}

This study used secondary data. The data were obtained through literature study from related sources. They were investment data of PMDN and PMA, employment and input-output of Central Java in 2013. Further, input-output table was mainly based on domestic transaction table data on producer price basis. Input-Output table of Central Java in 2013 is the latest year data published with 88 economic sector classification. The use of input-output analysis tables conducted in this study based on classification of 9 sectors of aggregation results of domestic transaction table on producer price basis of Table Input-Output Central Java Year 2013. Additionally, instrument used to process and analyze data was Microsoft Excel. While data source came from related agencies such as Central Bureau of Statistics (BPS) of Central Java Province and Regional Investment Board (BPMD) of Central Java
Province. This study also used analytical approach namely input-output analysis.

\section{RESULTS AND DISCUSSION}

\section{Inter-sectorial Linkage Analysis}

From Backward Linkages and Forward Linkages, the results of the analysis of inputoutput table of Central Java Province in 2013 based on 9 economic sector classification, the economic sectors of Central Java Province can be classified as follows.

Firstly, group 1, the leading sectors are sectors with Distribution Power Index (IDP) and Sensitivity Degrees (IDK) above average ( $\alpha j>1$ and $\beta_{\mathrm{i}}>1$ ) were manufacturing industrial and trade, hotels and restaurants sectors. Furthermore, manufacturing industrial sector had IDP of 1.04810 and IDK of 1.81070 , while trade, hotel and restaurant sectors had IDP of 1.01493 and IDK of 1.11136 .

Secondly, group 2 is sector index which has a high degree of sensitivity $\left(\beta_{i}>1\right)$ but has low spread power index $(\alpha j<1)$. It showed a sector which had high sensitivity toward other economic sectors changes. Indeed, the sectors which belong to this group were agricultural sector with IDP of 0.89098 and IDK of 1.01212 .

Thirdly, group 3 is sector index which had a low degree of sensitivity $\left(\beta_{i}<1\right)$ but has high spread power index $(\alpha j>1)$. This sector has high dependency. Sectors belong to this group were building, transportation and communication sectors. Building sector had IDP of 1.19614 and IDK of 0.83112 . Meanwhile, transportation and communications sectors had IDP of 1.17709 and IDK of 0.93492 .

Fourthly, group 4 is sector which lack of prospects. They are sectors that have low distribution power index and sensitivity degree index (below average). The sectors belong to this group were mining and quarrying sectors with IDP of 0.84077 and IDK of 0.74819 ; electricity, gas and water sector with IDP of 0.96704 and IDK 0.81836; financial, leasing and company services sectors with IDP of 0.87679 and IDK of 0.87306 ; services sector with IDP of 0.98815 and IDK of 0.86017 . 
Table 2. Economics Sector Classification of Central Java Province

\section{High Sensitivity Degree Index $\quad$ Low Sensitivity Degree Index}

\begin{tabular}{lll}
\hline High & Leading Sector & Potential Sector \\
Distribution & Manufacturing Industry & Building \\
Power & Trade, Hotel and Restaurant & Transportation and Communication \\
Index & & \\
\hline Low & Developed Sector & Underdeveloped Sector \\
Distribution & Agriculture & Mining and Quarrying \\
Power & & Electricity, Gas and Clean Water \\
Index & & Financial, Leasing and Company \\
& Services \\
& Services
\end{tabular}

Source: Analysis of Table I-O Central Java 2013, processed

Afterwards, the classification above is in line with fast growth theory. The theory explains that every country or region needs to see what sectors/ commodities which have great potential and can be quickly developed because of their natural potential or competitive advantage to develop.

\section{Multiplier Numbers Analysis}

Through multiplier numbers, it can be known that the impact of changes in certain sectors if there is a change in the final demand of another sector so the role of a sector to another in the economy of a region can be found. In this study, the multiplier figures seen are output and employment multiplier.

Table 3. Economics Sector Output Multiplier of Central Java Province Year 2013

\begin{tabular}{llll}
\hline Code & \multicolumn{1}{c}{ Sector } & Output Multiplier & $\begin{array}{c}\text { Employment } \\
\text { Multiplier }\end{array}$ \\
\hline 1 & Agriculture & 1.44605 & 0.04751 \\
2 & Mining and Quarrying & 1.06896 & 0.00961 \\
3 & Manufacturing Industry & 2.58701 & 0.01480 \\
4 & Electricity, Gas and Clean Water & 1.16922 & 0.00090 \\
5 & Building & 1.18745 & 0.01013 \\
6 & Trade, Hotel and Restaurant & 1.58784 & 0.02753 \\
7 & Transportation and Communication & 1.33576 & 0.01023 \\
8 & Financial, Leasing and Company Service & 1.24738 & 0.01312 \\
9 & Services & 1.22896 & 0.02666 \\
\hline
\end{tabular}

Source: Analysis of Table I-O Central Java 2013, processed

Based on the table above, it can be figured out that the manufacturing industry sector has the highest output multiplier value of 2.58701 . It means that every increase in demand for manufacturing sector output by $\mathrm{Rp} 1$ will affect the increase of overall economic output of Rp2.58701. Besides, the results of employment multiplier analysis showed that all economy sectors in Central Java have employment multiplier under $1(<1)$, while agricultural sector had the highest labor multiplier value of 0.04751 . Hence, if there is an increase in agricultural output of Rp100 will cause an increase in labor absorption in economy of 5 people.

This multiplier effect analysis is in accordance with multiplier effect concept theory 
proposed by Tarigan (2002: 139). He states that multiplier effect occurs when there is one sector caused by demand from outside of its production area increases because of a certain linkage. It affects many other sectors increase their production. Furthermore, there will be several rounds of increase, consequently the total increase in production can be multiply rather than the increase in external demand for the sector.

\section{Investment Impact toward Output and Employment Analysis}

This study partially analyzed the impact of final demand toward output. It covered the component of investment demand of PMDN and PMA toward output to see the role of investment of a sector toward output formation and investment impact on the absorption of sectorial labors in Central Java Province.
The result of the impact analysis showed that the result of final investment demand to output were trade, hotel and restaurant sector, while manufacturing industry sector and agricultural sector had the highest value of output impact and employment absorption due to private investment.

Moreover, trade, hotel and restaurant sector with output value due to final investment demand was $559,311,735$. It means that every increase of investment in those sectors amounted to $\mathrm{Rp} 1$ million, then their outputs would also increase by Rp559, 311.735, so manufacturing sector and agricultural sector will. For more, the magnitude of output increases due to investment in the sector is line with the value of investment final demand impact on output in that sector.

Table 4. Investment Final Demand Impact toward Output

\begin{tabular}{llll}
\hline Code & \multicolumn{1}{c}{ Sector } & Investment & \multicolumn{1}{c}{$\begin{array}{c}\text { Number of Labor } \\
\text { Absorption }\end{array}$} \\
\hline 1 & Agriculture & $80,559.751$ & 2.647 \\
2 & Mining and Quarrying & $1,833.639$ & 16 \\
3 & Manufacturing Industry & $529,920.408$ & 3.032 \\
4 & Electricity, Gas and Clean Water & $21,156.014$ & 16 \\
5 & Building & $16,509.771$ & 141 \\
6 & Trade, Hotel and Restaurant & $559,311.735$ & 9.699 \\
7 & Transportation and Communication & $49,733.709$ & 381 \\
8 & Financial, Leasing and Company & $35,580.395$ & 374 \\
9 & Services & $74,269.945$ & 1.611 \\
\hline
\end{tabular}

Source: Analysis of Table I-O Central Java 2013, processed

The value of employment due to investment in trade, hotel and restaurant sectors was 9,699. It means that every increase of investment in trade, hotel and restaurant sector of Rp1 million will absorb the labor of 9,699 people. Similarly, it also happened to manufacturing sector and the agricultural sector. Moreover, the magnitude of labor absorption due to investment in the sector was proportional to the value of the impact of the final investment demand on employment in the sector. The results of this study indicate that investment, output and employment are interrelated and affect each other. Additionally, any increased investment will increase output value. Again, increase output will increase employment in the economic sector. This is accordance with the results of earlier similar research. Those researches state that the Impact of Demand (Private Investment) has a positive relationship to the formation of output and employment (Darwis Amin, 2014).

\section{CONCLUSION}

The inter-sectorial linkages in Central Java Province analyzed by Input-Output Table of 2013 
show that sectors with high future linkages are agriculture, manufacturing and trade, hotel and restaurant sectors. Meanwhile, the sectors with high backward linkages are manufacturing, building, trade, hotel and restaurant, transport and communications sectors. Then, based on the analysis of future and backward linkages, it can be concluded that economy sectors which belong to leading sector are the manufacturing industrial and trade, hotels and restaurants sectors. In addition, the sector which has strong carrying capacity (growing sector) is agricultural sector. Also, the sectors which have high dependence (potential sector) are building and transportation and communications Sectors. At last, the less prospective sectors (mining sector) are mining and quarrying, electricity, gas and water supply, financial, leasing and company services and services sector.

The next conclusion is that the multiplier figures in Central Java Province based on InputOutput Table analysis in 2013 show that manufacturing sector become the highest output multiplier sector and the agricultural sector has the highest labor score in Central Java Province. Furthermore, the impact of changes in output value and the impact of labor absorption based on analysis of Input-Output Table of 2013 in Central Java Province shows that sectors with highest output and labor impact due to private investment in Central Java Province are trade, hotel and restaurant, manufacturing industry and agricultural sectors.

\section{REFERENCES}

Amin, Darwis. 2014. Dampak Investasi terhadap Penyerapan Tenaga Kerja di Provinsi Maluku: Analaisis Input-Output. Jurnal Program Studi Ekonomi Islam Fakultas Syariah dan Ekonomi Islam IAIN Ambon. Ambon.

Anas, M. (2015). Peranan Sektor Industri Pengolahan dalam Perekonomian Provinsi Jawa Tengah dengan Pendekatan Analisis Input Output. Economics Development Analysis Journal, 4(3). doi:10.15294/edaj.v4i3.7807

Arsyad, Lincoln. 2010. Ekonomi Pembangunan Edisi 5. Yogyakarta: UPP STIM YKPN Yogyakarta.

As'har, Hikmawan Adi. 2015. Pola Keterkaitan Antar Faktor yang Mempengaruhi Penyerapan
Tenaga Kerja oleh Sektor UMKM di Indonesia. Jurnal Ilmiah. Universitas Brawijaya. Malang.

Badan Koordinasi Penanaman Modal. 2015. Rencana Strategis Badan Koordinasi Penanaman Modal Tahun 2015-2019. Badan Koordinasi Penanaman Modal. Jakarta.

Badan Pusat Statistik. 2013. Jawa Tengah Dalam Angka Tahun 2013. Badan Pusat Statistik Provinsi Jawa Tengah. Semarang.

Badan Pusat Statistik. 2014. Jawa Tengah Dalam Angka Tahun 2014. Badan Pusat Statistik Provinsi Jawa Tengah. Semarang.

Badan Pusat Statistik. 2008. Kerangka Teori dan Analisis Tabel Input-Output. Badan Pusat Statistik. Jakarta.

Badan Pusat Statistik. 2014. Statistik Indonesia 2014. Badan Pusat Statistik. Jakarta.

Badan Pusat Statistik. 2014. Tabel Input Output Jawa Tengah 2013. Badan Pusat Statistik Provinsi Jawa Tengah. Semarang.

Badan Pusat Statistik. 2008. Teknik Penyusunan Tabel Input-Output. Badan Pusat Statistik. Jakarta.

Faleiros, João Paulo Martin, et al. 2016. Evaluating the effect of exchange rate and labor productivity on import penetration of Brazilian manufacturing sectors. EconomiA, 17(1), pp.322

Firmansyah. 2006. Operasi Matrix dan Analisis InputOutput untuk Ekonomi-Aplikasi Praktis dengan Microsoft Excel dan MATLAB. Semarang: Badan Penerbit Universitas Diponegoro dan Laboratorium Studi Kebijakan Ekonomi (LSKE) FE-UNDIP.

Jamaliah. 2016. The Effect of Investment to Value Added Production, Employment Absorption, Productivity, and Employees' Economic Welfare in Manufacturing Industry Sector in West Kalimantan Province. Procedia - Social and Behavioral Sciences, 219, pp.387-393.

Jhingan, M.L. 2008. Ekonomi Pembangunan dan Perencanaan. Jakarta: Raja Grafindo Persada.

Junaidi. 2014. Analisis Input-Output dengan Microsoft Office Excel. Seri Tutorial Analisis Kuantitatif. Universitas Jambi. Jambi.

Kuncoro, Mudrajad. 2007. Metode Kuantitatif-Teori dan Aplikasi untuk Bisnis dan Ekonomi. Yogyakarta: Unit Penerbit dan Percetakan (UPP) STIM YKPN.

Marouani, Mohamed A. and Björn Nilsson. 2016. The labor market effects of skill-biased technological change in Malaysia. Economic Modelling, 57, pp.55-75. 
Pemerintah Provinsi. 2016. Rencana Kerja Pemerintah Daerah Provinsi Jawa Tengah 2016. Pemerintah Provinsi Jawa Tengah.

Pemerintah Provinsi. Rencana Pembangunan Jangka Menengah Daerah Provinsi Jawa Tengah 2013-2018. Pemerintah Provinsi Jawa Tengah. Setiawan, Achma Hendra. Analisis Penyerpan Tenaga Kerja Pada Sektor Usaha Kecil dan Menengah (UKM) di Kota Semarang. JEJAK: Jurnal Ekonomi dan Kebijakan, [S.1.], v. 3, n. 1, Dec. 2015. ISSN 2460-5123 http://journal.unnes.ac.id/nju/index.php/jej ak/article/view/4663. Date accessed: 28 Jun. 2016.

Subanti, sri dan Arif Rahman Hakim. 2009. Ekonomi Regional Provinsi Sulawesi Tenggara: Pendekatan Sektor Basis dan Analisis InputOutput. Jurnal Ekonomi dan Studi Pembangunan Vol. 10 No. 1, April 2009.

Tarigan, Robinson. 2007. Ekonomi Regional Teori dan Aplikasi. Jakarta: Bumi Aksara.

Todaro, P. Michael. 2000. Pembangunan Ekonomi di Dunia Ketiga. Jakarta: Erlangga. 